Мушастая Н.П.

\title{
Синдром эмоционального выгорания у сотрудников МЧС как показатель профессиональной дезадаптации*
}

Синдром эмоционального выгорания (СЭС) является одним из аспектов профессиональной деформации личности и представляет собой приобретенный стереотип эмоционального поведения, чаще всего профессиональной и личностной дезадаптации. Исследование эмоционального выгорания позволяет разработать траектории психологического сопровождения по декомпенсации личностных деформаций, сотрудников, работающих в экстремальных условиях.

Традиционно и в общественном сознании, и в научной литературе при изучении профессиональной деятельности специалистов социономических профессий акцент делается, прежде всего, на позитивных аспектах работы с людьми. Вместе с тем совершенно очевидно, что именно работа с людьми в силу предъявляемых ею высоких требований, особой ответственности и эмоциональных нагрузок потенциально содержит в себе опасность тяжелых переживаний, связанных с рабочими ситуациями, и вероятность возникновения профессионального стресса.

По мнению исследователей, негативные психические переживания и состояния могут затрагивать разные грани трудового процесса - профессиональную деятельность, личность профессионала, профессиональное общение, в целом отрицательно сказывается на профессиональном развитии личности.

Исследуя разнообразные негативные психические состояния, возникающие вследствие экстремальных факторов: стресс, фрустрация, кризис, депривация, конфликт. Эти состояния характеризуются доминированием острых или хронических негативных эмоциональных переживаний: тревоги, страха депрессии, агрессии, раздражительности, дисфории. Возникающие в этих состояниях аффекты могут достигать такой степени интенсивности, что они оказывают дезорганизующее воздействие на интеллектуально - мнестическую деятельность человека, затрудняя процесс адаптации к происходящим событиям. Интенсивные эмоциональные переживания, также как страх, паника, ужас отчаяние, могут затруднять адекватное восприятие действительности, правильную оценку ситуации, мешая принятию решений и нахождению адекватного выхода из стрессовой ситуации.

Целью нашего исследования было изучение влияния профессиональной деятельности на развитие СЭВ у сотрудников МЧС.

* Материалы представлены научным руководителем - зав.кафедрой общей психологии ЮФУ, доктором психологических наук, профессором Абакумовой И.В. 
Мы использовали методику, оценки уровня эмоционального выгорания В.В. Бойко. В анонимном исследовании участвовали сотрудники поиского -спасательного отряда города Новороссийска.

Всего ответили на анкету 197 респондентов (98,5\%). Все опрошенные были мужского пола в возрасте 21-65 лет, из них 74,25 \% в возрасте старше 45 лет, 63,84\% имели стаж работы более 10 лет. В основе выбора места работы большинство сотрудников указали такие факторы, как материальная заинтересованность (88,1\%), большой трудовой отпуск (92,2\%), профессиональный интерес отметили только 35,12\%.

Методика диагностики уровня эмоционального выгорания Бойко В.В. позволяет оценить формирование СЭС в соответствии со стадиями общего адаптационного синдрома (напряжение, резистенция, истощение) и определить выраженность 12 симптомов, соответствующих синдрому выгорания.

В целом в группе исследуемых признаки синдрома эмоционального выгорания имели 62,9\% опрошенных, что оценивается по наличию формирующихся либо сформированных фаз синдрома.

Доминировала фаза «Напряжения» - 55,9\%. Полностью эта фаза сформировалась у 11,7\% опрошенных, которые имели по количеству баллов соответственно 62-78.

В этой фазе превалируют симптомы переживания психотравмирующих обстоятельств 17,6 \%, тревоги и депрессии 63,2\%, что проявляется ощущением физических или психологических перегрузок, напряжением на работе, наличием конфликтов с коллегами.

Достаточно выражена и фаза «Резистенция» - 26,5\%. В этой фазе превалируют симптомы переживания психотравмирующих обстоятельств

Это появляется неадекватным эмоциональным реагированием на пациентов и своих коллег, отсутствием эмоциональной вовлеченности, утратой способности к сопереживанию пострадавшим, усталостью, ведущей к редукции профессиональных обязанностей и негативному влиянию работы на личную жизнь.

Выраженную фазу «истощения» никто из опрошенных не имел, но, тем не менее, симптом «эмоциональный дефицит» как сложившийся симптом имели 8,8\% респондентов, возраст которых 51 - 60 лет и стаж работы более 10 лет

Соотношение стажа работы и степени эмоционального выгорания показало, что показатели выше среднего имели 50,2\% со стажем работы менее 3 лет и 43,7\% со стажем более 10 лет, тогда как у остальных опрошенных эти показатели превышали среднее значения только в 23,7\% случаев.

Проведенное нами исследование позволяет проанализировать показатели адаптации к профессиональной деятельности и влияния профессиональной деятельности на развитие СЭС. 